\title{
IDENTIFIKASI GLUKOSILTRANSFERASE (gtf) PENYANDI EKSOPOLISAKARIDA PADA STRAIN Weisella confusa PROBIOTIK ASAL AIR SUSU IBU (ASI)
}

\section{Identification Glycosiltransferase (gtf) as Exopolysaccharides Producer in Strains Weisella confusa Probiotic from Human Breastmilk}

\author{
Nosa Septiana Anindita \\ Program Studi Bioteknologi, Fakultas Sains dan Teknologi, Universitas 'Aisyiyah Yogyakarta \\ Jl. Siliwangi (Ringroad Barat) No. 63 Mlangi Nogotirto, Gamping, Sleman, \\ Yogyakarta 55292 \\ Penulis Korespondensi, Email: anindita.nosa@yahoo.com
}

\begin{abstract}
ABSTRAK
Identifikasi gen gtf dan kemampuan produksi EPS digunakan sebagai parameter dalam seleksi isolat probiotik yang memenuhi syarat Generally Recognized as Safe (GRAS). Penelitian ini bertujuan sebagai salah satu upaya dalam memperoleh isolat lokal kandidat probiotik potensial indigenus asal ASI sebagai penghasil EPS. Metode penelitian ini meliputi identifikasi gen gtf menggunakan primer spesifik (DegFor dan DegRev) dan produksi EPS selama fermentasi. Berdasarkan hasil studi, identifikasi keberadaan gen gtf pada 4 strain Weisella confusa asal ASI terdeteksi pada 660 bp dan Weisella confusa strain AS3 memiliki kemampuan menghasilkan EPS tertinggi yaitu $1883 \pm 56 \mathrm{mg} / \mathrm{L}$. Sehingga, Weisella confusa kandidat probiotik potensial asal ASI memiliki kemampuan produksi EPS berdasarkan identifikasi molekuler dan produksi EPS selama fermentasi.
\end{abstract}

Kata kunci: Air susu ibu (ASI), Eksopolisakarida, Glukosiltransferase (gtf), Weisella confusa

\section{ABSTRACT}

Identification of gtf gene and the ability to produce EPS is used as a parameter in the selection of probiotic isolates that Generally Recognized as Safe (GRAS) requirements. This research aimed as one of the efforts to obtain local isolates of potential probiotic candidates indigenous from human breast milk as for EPS production. This research method included the identification of gtf genes using specific primers (DegFor and DegRev) and EPS production during fermentation. Based on study results that the identification of the gtf gene in 4 Weisella confusa strains from breast milk was detected at $660 \mathrm{bp}$ and the Weisella confusa AS3 strain had the highest ability to produce EPS, $1883 \pm 56 \mathrm{mg} / \mathrm{L}$. Thus, Weisella confusa as a potential probiotic candidate from human breast milk had the ability to produce EPS based on molecular identification and EPS production during fermentation.

Keywords: Exopolysaccharides, Glycosiltransferase (gtf), Human Breastmilk, Weisella confusa

\section{PENDAHULUAN}

Pola hidup masyarakat dalam mengkonsumsi pangan fungsional telah terjadi perubahan. Hal ini didukung oleh meningkatnya kesadaran dan pengetahuan masyarakat terhadap pola hidup sehat. Kelompok Bakteri Asam Laktat (BAL) telah memberikan kontribusi besar dalam pemanfaatannya pada pangan fungsional sebagai probiotik. Carr et al. (2010) melaporkan beberapa aktivitas metabolisme probiotik yang berimplikasi positif bagi kesehatan manusia diantaranya pencegahan terhadap lactose intolerance, mencegah terjadinya kanker usus besar dan penurunan kadar kolesterol darah. BAL merupakan 
golongan bakteri yang bermetabolisme dengan asam laktat dan sebagai produk utama dalam fermentasi karbohidrat.

Eksplorasi BAL dari berbagai macam sumber, saat ini semakin meningkat. BAL dapat diisolasi dari berbagai makanan fermentasi untuk digunakan sebagai probiotik dan pangan fungsional (Solieri et al., 2014). Selain itu, BAL juga dapat diisolasi bersumber pada sampel asal manusia seperti ASI dan fekal material bayi. Air susu ibu (ASI) merupakan sumber potensial dalam memperoleh probiotik. Keunggulan probiotik yang berasal dari tubuh manusia seperti ASI memiliki viabilitas tinggi pada saluran pencernaan dan lebih adaptif jika diaplikasikan dalam produk pangan. Menurut Ozgun and Vural (2011), probiotik umumnya berasal dari golongan BAL. Genus BAL yang digunakan sebagai probiotik, mayoritas berasal dari genus Lactobacillus dan Bifidobacterium. Genus tersebut sering diisolasi saluran pencernaan manusia dan memang merupakan flora alami saluran pencernaan.

Isolat BAL asal ASI juga telah berhasil diisolasi, isolat BAL tersebut memiliki kemampuan menurunkan kolesterol Pediococcus pentosaceus 1-A38 (Nuraida et al., 2011). Penelitian lain juga telah berhasil mengisolasi BAL dari ASI berumur 4 bulan. Isolat BAL terpilih menunjukkan Lactobacillus fermentum JCM3 memiliki kemampuan sebagai probiotik (Serrano-Nino et al., 2016). Eksplorasi BAL asal ASI juga telah dilakukan dengan memperoleh 13 isolat BAL asal ASI dengan beragam genus yaitu Lactobacillus, Weisella dan Pediococcus. Identifikasi secara molekuler melalui primer spesifik untuk BAL dilanjutkan dengan primer universal 16s rRNA memperoleh 13 isolat BAL yang terdiri atas 6 Lactobacillus paracasei, 2 Lactobacillus casei, 2 Pediococcus acidilactici dan masingmasing 2 isolat lainnya adalah Lactobacillus plantarum serta Weisella confusa. Pada penelitian ini juga dilakukan pengujian terkait potensi probiotik dari ke-13 isolat yang telah teridentifikasi. Berdasarkan hasil pengujian potensi probiotik, ke-13 isolat asal ASI tersebut memiliki potensi probiotik secara in vitro melalui beberapa parameter yaitu ketahanan terhadap asam lambung $(\mathrm{pH} 2)$ dan garam empedu $(0,3 ; 0,5 ; 1,0$ dan $1,5 \%)$, penghambatan terhadap patogen dan pemanfaatan prebiotik inulin (Anindita et al., 2018). Penelitian lain juga dilaporkan oleh Widodo et al. (2012) yang telah berhasil mengisolasi BAL asal fekal material bayi yang berpotensi sebagai probiotik.

Umumnya, probiotik memiliki kemampuan tahan terhadap $\mathrm{pH}$ rendah, garam empedu dan menghasilkan senyawa bakteriosin. Namun, kemampuan adhesi pada mukosa usus menjadi salah satu karakteristik probiotik yang menarik untuk dipelajari. Hal ini disebabkan karena probiotik mampu mensekresikan eksopolisakarida (EPS) yang berperan dalam adhesi (penempelan) pada dinding saluran pencernaan. Kemampuan BAL dalam mensekresikan EPS menjadi informasi penting dimana telah banyak dilaporkan terkait manfaatnya bagi kesehatan. Sanlibaba and Cakmak (2016), EPS merupakan polimer biodegradable hasil biosintesis berbagai organisme dengan berat molekul tinggi. Nanda and Raghavan (2014) menjelaskan bahwa EPS sering ditemukan pada struktur terluar prokariotik serta sel-sel eukariotik. Hal ini berhubungan dengan pembentukan kapsul sel ataupun mukus yang diekskresikan oleh permukaan sel. EPS terdapat dalam berbagai macam struktur kimia unik dan kompleks, memberikan perlindungan diri terhadap senyawa antimikrobia yang berada di dekatnya dan dapat dijadikan sebagai cadangan karbon dan energi.

EPS yang dihasilkan dari BAL telah banyak dilaporkan dengan sejumlah fungsi kesehatan (Caggianiello et al., 2016). Beberapa fungsi kesehatan diantaranya imunostimulasi (Hidalgo-Cantabrana et al., 2012), aktivitas antioksidan (Polak-Berecka et al., 2015), antitumor (Nishimura, 2014) dan penurunan kolesterol darah (Ryan et al., 2015). Selain itu EPS berperan dalam melindungi sel BAL dari lingkungan berbahaya dan mendukung dalam adhesi dan biofilm. EPS juga dilaporkan berperan dalam teknologi pangan seperti pembentukan tekstur dan reologi (Torino et al., 2015). Oleh karena itu, produksi EPS menjadi properti yang menarik untuk dipertimbangkan dalam pemilihan strain probiotik. 
EPS juga berperan dalam proses perlindungan sel bakteri dari kekeringan, mempertahankan fungsi seluler primer dan aktivitas antibakteri terhadap predator, kemampuan pembentuk gel dan degradasi polutan (Rawal et al., 2016).Terdapat dua jenis utama EPS menurut komponen penyusunnya yaitu homo- dan hetero-EPS. Saat ini, EPS telah banyak dimanfaatkan secara luas dalam berbagai aplikasi dalam pangan, farmasi dan industri lainnya (Nwodo et al., 2012). EPS telah terbukti memiliki aktivitas fisiologis seperti antitumor, antivirus dan antiinflamasi, serta menjadi penginduksi interferon, penghambatan agregasi trombosit, sintesis faktor penstimulasi koloni, koagulan dan pelumas ( $\mathrm{Li}$ et al., 2016; Venkateswarulu et al., 2016).

Produksi EPS pada probiotik dipengaruhi oleh keberadaan gen penyandi enzim glukosiltransferase yang berperan dalam reaksi pembentukan EPS, salah satu gen tersebut yaitu gen glukosiltransferase ( $g t f)$. Gen gtf yang berasal dari BAL memiliki pola organisasi struktural gen yang mayoritas sama, dengan empat macam bagian penyusun. Bagian penyusun gen gtf tersebut, yaitu: (a) daerah terminal-N peptida, (b) daerah dengan urutan variasi yang tinggi, (c) daerah pengikatan sukrosa dan katalitik yang sangat conserved dan (d) daerah terminal-C (Monchois et al., 2009). Polimorfisme dari gen gtf tersebut dipengaruhi oleh asal dan spesies galur BAL. Adanya identifikasi dan skrining gen gtf pada suatu isolat akan memberikan dampak terhadap variasi enzim yang berperan dalam sintesis EPS sehingga akan menimbulkan variasi polimer EPS dan manfaatnya dalam bidang farmasi, kesehatan dan pangan (Malik et al., 2009).

Stack et al. (2010) membuktikan bahwa Lactobacillus paracasei NFBC 338 mampu mengekspresikan gen gtf dan memiliki kemampuan sebagai probiotik yang potensial. Fukao et al. (2019) berhasil mengidentifikasi gen gtf dari Lactobacillus brevis KB290 yang berasal dari acar tradisional Jepang. Enam strain Lactobacillus asal makanan tradisional Malaysia memiliki kemampuan menghasilkan EPS (Khalil et al., 2018). Identifikasi sekuen genom penyandi EPS Lactobacillus brevis juga telah berhasil dilakukan (Fraunhofer et al., 2017). Produksi EPS Bifidobacterium longum asal fekal lansia dan bayi melalui analisis gen glikosiltransferase ( $g t f$ ) dan kemampuannya sebagai probiotik juga telah berhasil dilaporkan (Yan et al., 2017). Skrining gen penyandi EPS pada Lactobacillus dan Bifidobacterium asal usus manusia telah berhasil dilakukan (Ruas-Madiedo et al., 2007). Kemampuan Lactobacillus lactic ssp. lactis asal susu segar dalam memproduksi EPS menunjukkan kemampuan tinggi pada $\mathrm{pH}$ lingkungan sebesar 6.5 dan suhu $37{ }^{\circ} \mathrm{C}$ telah dilaporkan (Gayathiri et al., 2017).

Identifikasi gen dan kemampuan produksi EPS ini digunakan sebagai parameter dalam seleksi isolat probiotik yang memenuhi syarat Generally Recognized as Safe (GRAS). Potensi isolat lokal BAL sebagai probiotik asal ASI ini diharapkan mempunyai kemampuan adaptasi tinggi terhadap kondisi lokal dan terjamin ketersediaannya dalam pembuatan pangan fungsional (Functional Food) atau pangan kesehatan (Nutraceutical Food). Hasil penelitian yng dilakukan oleh Anindita et al. (2018) menunjukkan beberapa strain Weisella confusa telah terbukti memiliki potensi probiotik secara in vitro berdasarkan beberapa parameter yaitu ketahanan terhadap asam lambung $(\mathrm{pH} 2)$ dan garam empedu $(0.3 ; 0.5 ; 1$ dan $1.5 \%$ ), penghambatan terhadap patogen dan pemanfaatan prebiotik inulin. Namun belum diketahui apakah keempat strain Weisella confusa tersebut memiliki gen penyandi EPS dan kemampuan produksi EPS selama fermentasi.

\section{BAHAN DAN METODE}

\section{Bahan}

Strain Weisella confusa yang menjadi subyek dalam penelitian ini merupakan isolat asal ASI yang telah terbukti memiliki potensi sebagai probiotik secara in vitro pada penelitian sebelumnya. Isolat probiotik indigenus yang diperoleh dari hasil isolasi ASI yaitu Weisella confusa AS3, Weisella confusa AS14, Weisella confusa AS18 dan Weisella confusa AS21 (Anindita et al., 2018). Bahan untuk rekultur isolat yang digunakan antara lain de Mann 
Rogose Sharpe Broth dan Agar dari Merck, L-cystein HCl (Sigma), garam Oxgall (Difco), alkohol $75 \%$, alkohol 96\%, kapas, aquades, spiritus, cotton swab sterile (Oxoid).

Bahan untuk isolasi DNA antara lain hidroksimetil aminometana (Merck), EDTA (Merck), $\mathrm{NaCl}$ (Merck), enzim lisosim (Merck), SDS (Merck), fenol (Merck), kloroform (Merck), isopropanol (Merck), Na2-EDTA (Amersham Bioscience), RNAse A (Thermo Scientific) serta proteinase $\mathrm{K}$ (AppliChem). Penanda DNA untuk elektroforesis adalah DNA ladder berukuran $1 \mathrm{~kb}$ (Promega, Madison USA). Bahan untuk elektroforesis DNA yaitu etidium bromida (Merck), loading dye (Thermo Scientific), sedangkan agarose (Promega, Madison USA).

Bahan untuk amplifikasi DNA antara lain GoTaq Green PCR Master Mix (Thermo Scientific), water nuclease-free (Thermo Scientific), Primer untuk amplifikasi BAL dari $1^{\text {st }}$ Base yaitu forward plb16 (5'-AGAGTTTGATCCTGGCTCAG-3') dan primer reverse m/b16 (5'-GGCTGCTGGC-ACGTAGTTAG-3') seperti yang tercantum dalam Malik et al. (2009) dan primer spesifik gen gtf dari $1^{\text {st }}$ Base yaitu primer DegFor 5'GAYAAYWSNAAYCCNRYNGTNC-3' dan DegRev 5'ADRTCNCCRTARTANAVNYKNG-3 seperti yang tercantum dalam Malik et al. (2008). Penanda DNA untuk proses elektroforesis adalah DNA ladder berukuran 100 bp dari Promega (Madison, USA). Bahan untuk produksi EPS kasar meliputi aseton 99\% (Merck) dan asam trikloroasetat (Merck).

\section{Alat}

Beberapa alat dalam penelitian ini meliputi laminar air flow (LAF) (Telstar Bio-II-A/P), lemari asam (Fumhood), inkubator (Memmert), waterbath (Techne Shaking Bath 58-16), sentrifuge (Eppendorf 5804R), mikroskop (OptiLab L301), optic glass, pH meter (Hanna S 382632), PCR cycler (Boeco TC-SQ), submarine electrophoresis system (Mupid exu), DNA Analyzer (Applied Biosystem 3730xI), UV-VIS (Milton Roy Spectronic 1001), vorteks (Maximix I type 16700), heater (Cimarec 3), timbangan analitik (AND GR-200), mikropipet 100$1000 \mu \mathrm{l}$ (Accura 821), mikropipet 5-50 $\mu \mathrm{l}$ (Socorex), mikrotip (Eppendorf), mikrotube (Axygen) dan glassware (Pyrex).

\section{Desain Penelitian}

Penelitian ini dilakukan melalui penelitian deskriptif yang terdiri dari 2 langkah utama yaitu identifikasi molekuler dan produksi EPS kasar.

\section{Tahapan Penelitian}

Penelitian ini memliliki 4 tahapan penelitian yaitu (1) Reculture Isolat terpilih, (2) Isolasi DNA genomik BAL, (3) Amplifikasi gen gtf dengan primer DegFor dan DegRev dan (4) Produksi EPS kasar.

\section{Metode}

\section{(1) Reculture isolat probiotik}

Reculture isolat probiotik menggunakan metode Serrano-Nino et al. (2016) dengan modifikasi. Isolat probiotik asal ASI ditumbuhkan secara aseptis dalam medium MRSB yang telah disuplementasi dengan $\mathrm{L}$-cystein $\mathrm{HCl} 0.05 \%$ dan oxgall $0.15 \%$ serta diinkubasi selama 48 jam, suhu $37^{\circ} \mathrm{C}$.

\section{(2) Isolasi DNA Genom}

Isolasi DNA genom mengacu pada metode Song et al. (2004) dengan modifikasi. Isolat probiotik yang telah direculture dipanen ke dalam mikrotube $1.5 \mathrm{ml}$. Suspensi kemudian disentrifugasi pada 13000 rpm, 5 menit. Supernatan kemudian dibuang, pelet yang diperoleh diresuspensi dalam $400 \mu \mathrm{l}$ buffer TE, disentrifugasi pada $13000 \mathrm{rpm} 5$ menit. Selanjutnya, supernatan dibuang dan pelet diresuspensi dalam $400 \mu$ l buffer SET $(75 \mathrm{mM}$ $\mathrm{NaCl}, 25 \mathrm{mM}$ EDTA, $20 \mathrm{mM}$ Tris- $\mathrm{HCl}, \mathrm{pH}$ 7,5) dan ditambahkan $50 \mu \mathrm{l}$ lisosim. Larutan dihomogenkan dan diinkubasi dalam waterbath suhu $37^{\circ} \mathrm{C}$ selama 1 jam dengan diselingi inversi setiap 15 menit. Setelah inkubasi, ditambahkan $50 \mu \mathrm{l}$ SDS $10 \%$ dan diinkubasi 
kembali dalam waterbath suhu $65 \stackrel{\circ}{\circ}$ selama 2 jam. Setelah 1 jam, ditambahkan $167 \mu$ l larutan $\mathrm{NaCl} 5 \mathrm{M}$.

Setelah inkubasi selesai, sebanyak $400 \mu \mathrm{l}$ kloroform dingin ditambahkan dan diinkubasi pada suhu kamar 30 menit dengan diselingi inversi setiap 10 menit. Suspensi kemudian disentrifugasi $13000 \mathrm{rpm} 10$ menit. Setelah sentrifugasi, lapisan cair atas dipindahkan ke mikrotube $1.50 \mathrm{ml}$ yang baru. Isopropanol dengan volume yang sama ditambahkan ke dalam tabung dan dihomogenkan. Suspensi kemudian diinkubasi suhu -20 ${ }^{\circ} \mathrm{C}$ selama semalam. Tahapan selanjutnya dilakukan presipitasi DNA dengan sentrifugasi sampel pada $13000 \mathrm{rpm}, 10$ menit. Supernatan dibuang kemudian $500 \mu \mathrm{l}$ etanol $70 \%$ ditambahkan, diinversi, dan sentrifugasi kembali 13000 rpm 10 menit. Supernatan dibuang hingga tersisa pelet yang menempel pada dasar tabung. Pelet dalam tabung dikeringanginkan selama sekitar 2 sampai 4 jam hingga etanol menguap. Selanjutnya, ke dalam tabung ditambahkan $50 \mu \mathrm{l}$ buffer TE dan diresuspensi. Larutan DNA yang diperoleh dapat langsung digunakan atau disimpan suhu $-20{ }^{\circ} \mathrm{C}$. DNA dapat dianalisis secara kualitatif dengan elektroforesis pada agarose $0.8 \%(\mathrm{w} / \mathrm{v})$ dan divisualisasi pada UV illuminator dengan marker $1 \mathrm{~kb}$. Pita DNA akan tampak pada agarose manandakan keberadaan DNA.

\section{(3) Amplifikasi gen gtf}

Amplifikasi gen gtf menggunakan sekuen primer DegFor 5'GAYAAYWSNAAYCCNRYNGTNC-3' dan DegRev 5'ADRTCNCCRTARTANAVNYKNG-3. Siklus PCR meliputi Predenaturasi $95^{\circ} \mathrm{C}, 5$ menit, Denaturasi $95^{\circ} \mathrm{C}, 30$ detik; Annealing 42 ${ }^{\circ} \mathrm{C}, 45$ detik dan Elongasi $72{ }^{\circ} \mathrm{C}, 60$ detik, sebanyak 35 siklus dengan amplikon gen gtf berukuran 660 bp (Malik et al., 2008).

\section{(4) Produksi EPS kasar}

Produksi EPS kasar menggunakan metode yang dilakukan oleh Halim dan Elok (2013) dengan modifikasi. Isolat probiotik asal ASI ditumbuhkan pada media MRSB sebanyak $10 \mathrm{ml}$ dan disuplementasi dengan $\mathrm{L}$-cystein $\mathrm{HCl} 0.05 \%$ dan oxgall $0.15 \%$ inkubasi pada suhu $37{ }^{\circ} \mathrm{C}$. Selanjutnya sel dipanen mulai jam ke-24 atau memasuki fase stasioner dan dipindahkan pada MRSB sebanyak $15 \mathrm{ml}$, dan disentrifugasi dingin suhu $4{ }^{\circ} \mathrm{C}, 5000 \mathrm{rpm}$ selama 30 menit, sehingga akan terpisah antara supernatan dan biomassa bakteri (pellet). Sebagai perlakuan, sebanyak $10 \mathrm{ml}$ Supernatan diambil, ditambahkan $20 \mathrm{ml}$ (2x volume sampel) aseton dan didiamkan selama overnight. Campuran supernatan dan aseton selanjutnya di sentrifugasi pada conicle ukuran $15 \mathrm{ml}$ dan disentrifugasi suhu $4^{\circ} \mathrm{C}, 5000 \mathrm{rpm}$ 30 menit. Endapan yang berada di dasar tabung diindikasikan sebagai eksopolisakarida kasar. EPS kasar ini kemudian dilarutkan dengan $10 \mathrm{ml}$ aquades dan sebanyak $250 \mu \mathrm{l}$ asam trikloroasetat $80 \%$ ditambahkan yang berfungsi untuk mengendapkan protein-protein yang masih ada dan didiamkan pada suhu ruang, overnight. Selanjutnya dilakukan sentrifugasi kembali pada suhu suhu $4{ }^{\circ} \mathrm{C}, 5000 \mathrm{rpm} 30$ menit. Pelet hasil sentrifugasi selanjutnya dikeringkan suhu $100^{\circ} \mathrm{C} 15$ menit dan dilakukan penimbangan. Hasil penimbangan tersebut sebagai berat kering EPS beserta tabung. Berat EPS kasar dihitung dengan mengurangi berat tabung berisi EPS dengan berat tabung kosong sebelum perlakuan hingga didapatkan berat konstan, dengan selisih berat $\pm 0.02 \mathrm{mg}$.

\section{Prosedur Analisis}

Analisis data yang didapat berdasarkan pada pengujian kualitatif dan kuantitatif. Secara kualitatif, data diperoleh dengan melihat pita amplikon menggunakan gel documentation, sedangkan secara kuantitatif data diperoleh dari pengukuran produksi EPS kasar. 


\section{HASIL DAN PEMBAHASAN}

\section{DNA Genom}

Visualisasi elektroforegram DNA genom dapat dilihat secara kualitatif melalui elektroforesis pada agarose 1\%. Elektroforesis merupakan suatu teknik molekuler dasar untuk memisahkan molekul DNA berdasarkan ukuran (berat molekul). Gambar 1 berikut ini menunjukkan elektroforegram dengan pita yang menunjukkan bahwa DNA dari genom isolat berhasil diisolasi. Selanjutnya hasil isolasi DNA ini digunakan sebagai DNA template untuk proses amplifikasi melalui PCR dalam mengidentifkasi keberadaan gen penyandi EPS yaitu glukosiltransferase (gtf).

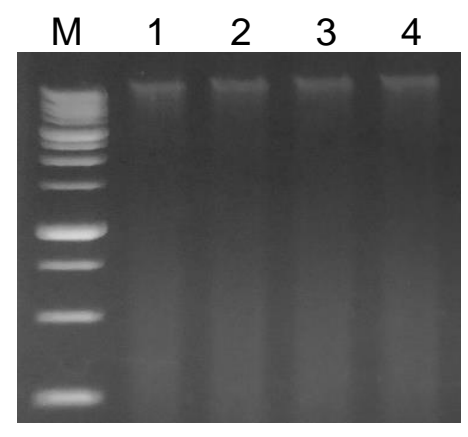

Gambar 1. Elektroforegram produk isolasi DNA beberapa strain Weisella confusa pada gel agarose 1,5\%, DNA ladder $1 \mathrm{~kb}$ (M: Marker; 1: Weisella confusa AS3; 2: Weisella confusa AS14; 3: Weisella confusa AS18 dan 4: Weisella confusa AS21)

\section{Amplifikasi gen gtf}

Amplifikasi gen gtf menggunakan sekuen primer DegFor 5'GAYAAYWSNAAYCCNRYNGTNC-3' dan DegRev 5'ADRTCNCCRTARTANAVNYKNG-3 (Malik et al., 2008). Siklus PCR meliputi Predenaturasi $95^{\circ} \mathrm{C}, 5$ menit, Denaturasi $95^{\circ} \mathrm{C}, 30$ detik; Annealing $42{ }^{\circ} \mathrm{C}, 45$ detik dan Elongasi $72{ }^{\circ} \mathrm{C}, 60$ detik, sebanyak 35 siklus dengan amplikon gen gtf berukuran 660 pb. Berdasarkan Gambar 2, dari 4 strain Weisella confusa, semuanya memiliki gen gtf dengan ditunjukkan adanya pita DNA pada ukuran 660 bp dengan ketebalan yang bervariasi untuk setiap isolat.

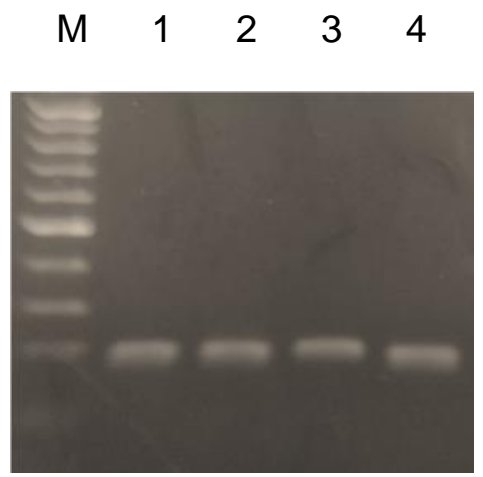

Gambar 2. Elektroforegram hasil amplifikasi gen gtf pada beberapa strain Weisella confusa pada gel agarose 1,5\%, DNA ladder 100 bp (M: Marker; 1: Weisella confusa AS3; 2: Weisella confusa AS14; 3: Weisella confusa AS18 dan 4: Weisella confusa AS21)

Deteksi molekuler keberadaan gen gtf juga dilakukan oleh Fraunhofer et al dengan menggunakan primer degenerate DegFor dan DegRev. Primer digunakan untuk mendeteksi adanya gen penyandi enzim Glukansukrase (Fraunhofer et al., 2017). Sekuens homolog pada ranah katalitik gen gtf dari Lb. Reuteri (gtfA), Streptococcus downei (gtfS), S. mutans ( $g t f C)$, S. downei (gtfl), S. salivarus (gtfK dan gtfM), serta dsrA Leuconostoc mesenteroides 
digunakan sebagai dasar dalam merancang primer degenerate tersebut. Amplifikasi fragmen DNA yang belum diketahui urutannya dapat memanfaatkan primer degenerate. (Gayathiri et al., 2017).

Peran gen gtf dalam produksi EPS pada probiotik menjadi penting untuk dipelajari. Metode molekuler seperti Polymerase Chain Reaction (PCR) dilakukan untuk identifikasi gen gtf. Primer yang digunakan untuk mengidentifikasi gen gtf adalah primer degenerate DegFor dan DegRev. Isolasi gen baru berdasarkan kesamaan sekuens DNA, sekuens asam amino, dan identifikasi gen-gen homolog pada organisme sekerabat yang memiliki kemiripan tinggi dapat dilakukan dengan memanfaatkan primer degenerate. Penggunaan primer degenerate ini dipilih karena telah terbukti efisien dan tepat dalam mengidentifikasi gen gtf pada bakteri probiotik penghasil EPS (Kralj et al., 2003).

Berdasarkan hasil elektroforegram (Gambar 2) menunjukkan bahwa 4 strain Weisella confuse terdeteksi memiliki gen gtf. Gen gtf memiliki panjang kurang lebih 660 bp (Malik et al., 2010). Gen gtf memiliki peran dalam sintesis polimer glukan dengan BM besar dari substrat sukrosa. Sukrosa adalah substrat donor untuk enzim glikosil hidrolase (GH), yang dinamai glucansucrase (famili GH70) yang mengkatalisasi sintesis a-glukan, dan terletak secara ekstraseluler (Meng et al., 2016; Gangoiti et al., 2018). Gen gtf berfungsi dalam reaksi hidrolisis Sukrosa menjadi monomer-monomer gula yang selanjutnya akan bergabung sehingga membentuk rantai polimer gula (poligula), yaitu EPS (Malik et al., 2008). Keberadaan gen gtf ini memiliki dampak langsung pada unit berulang dari polimer. Hal ini diperkuat oleh Ryan et al. (2015) dan Castro-Bravo et al. (2018) bahwa beberapa jenis gtf umumnya terlibat dalam penggabungan polisakarida ke dalam EPS pada Lactobacilli dan Bifidobacteria.

Malik et al. (2010) berhasil mengidentifikasi 13 galur bakteri asam laktat (BAL) asal pangan dengan kandungan gula, termasuk Weissella salipiscis, Weissella confusa dan Weissella cibaria. Yan et al. (2017) juga melakukan analisis gen gtf pada Bifidobacterium longum yang diisolasi dari feses lansia dan bayi. Fukao et al. (2019) mengidentifikasi gen gtf pada Lactobacillus brevis KB290, yaitu gen gtf27 dan gtf28 yang berperan dalam agregasi sel dan resistensi empedu. Banyaknya penelitian terdahulu terkait identifikasi gen gtf dari probiotik dapat memberikan keragaman pada gen gtf yang diperoleh. Sintesis beragam dari EPS homopolisakarida telah dilaporkan (Tieking et al., 2010), yaitu sintesis kedua macam EPS glukan dan fruktan pada Weissella confusa (Van Hijum et al., 2009) yang telah berhasil mengidentifikasi gen gtf pada genom Oenococcus oeni.

\section{Produksi Eksopolisakarida}

Setelah dilakukan kajian molekuler terkait kemampuan produksi EPS beberapa strain Weisella confusa asal ASI melalui keberadaan gen gtf, selanjutnya isolat-isolat tersebut diuji produksi EPS kasar selama pertumbuhan. Beberapa strain Weisella confusa asal ASI memiliki kemampuan dalam menghasilkan EPS dengan kadar yang bervariasi dari $1300-1800 \mathrm{mg} / \mathrm{L}$. Berdasarkan hasil pengujian produksi EPS kasar selama pertumbuhan (Gambar 3), Weisella confusa strain AS3 memiliki kemampuan tertinggi dalam memproduksi EPS selama pertumbuhan yaitu sebesar $1883 \pm 56 \mathrm{mg} / \mathrm{L}$, sedangkan kemampuan produksi EPS terendah dimiliki oleh Weisella confusa strain AS18 sebesar $1369 \pm 30 \mathrm{mg} / \mathrm{L}$. Kemampuan produksi EPS pada beberapa strain Weisella confusa ini berkorelasi positif dengan ditemukannya gen gtf pada strain-strain tersebut (Gambar 2) dengan ketebalan yang hampir sama.

Kemampuan produksi EPS ini juga bersifat strain dependent dimana dengan spesies yang sama, ternyata terbukti memiliki kemampuan yang bervariasi dalam produksi EPS. Hal ini didukung oleh pendapat Malik et al. (2009) bahwa asal dan spesies galur BAL akan berkontribusi terhadap kekayaan dan keragaman gen gtf yang akan mempengaruhi keragaman enzim dalam sintesis EPS sehingga akan terjadi variasi jenis-jenis polimer dan manfaatnya di industri farmasi, kesehatan dan pangan.

Produksi jumlah EPS sangat dipengaruhi oleh sifat genetis dan fenotif individu itu sendiri. Sifat genetis merupakan sifat turunan bawaan dari masing-masing spesies yang 
dipengaruhi oleh susunan gen, sedangkan sifat fenotif cenderung dipengaruhi oleh faktor lingkungan (Suryawira, 2011). Beberapa faktor seperti kondisi fermentasi, media pertumbuhan (suplementasi mineral), interaksi antar strain (co-culture fermentation) dan jenis teknologi fermentasi (fed-batch fermentation) juga mempengaruhi produksi EPS asal BAL (Badel et al., 2011).

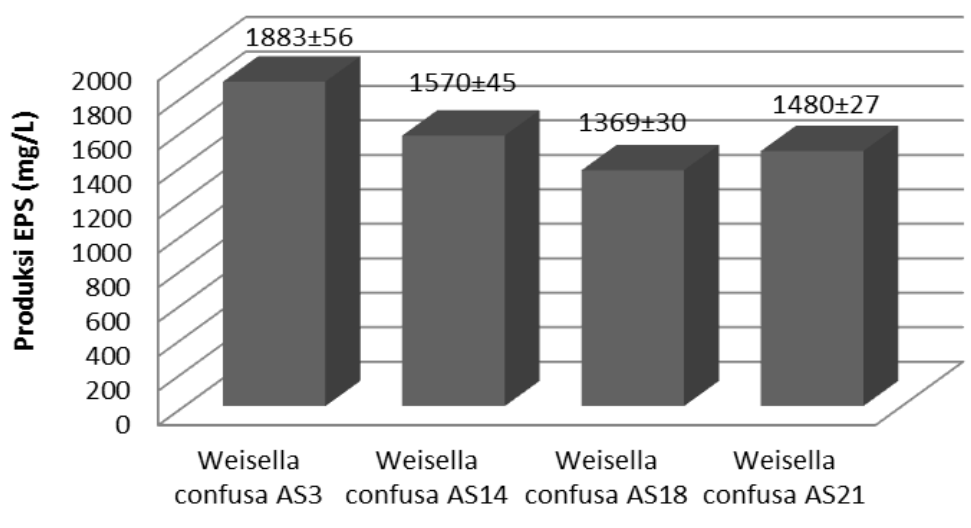

Isolat Kandidat Probiotik

Gambar 3. Produksi EPS (mg/L) oleh beberapa strain Weisella confusa asal ASI

Sifat fungsional probiotik terkait dengan produksi EPS dipengaruhi oleh gen penyandi enzim dalam reaksi pembentukan EPS. Menurut Peant et al. (2005) pembentukan genetik seperti regulasi pengkodean gen, perakitan unit berulang, penentuan panjang rantai, polimerisasi dan ekspor memainkan peran yang sangat penting dalam biosintesis EPS. Leivers et al (2011) menjelaskan bahwa pembentukan unit EPS dimulai dengan proses katalisasi oleh enzim glukosiltransferase. Enzim ini akan mengkatalisasi pembentukan ikatan glikosidik dengan mentransfer bagian gula baru dari gula nukleotida donor ke monosakarida awal. Selanjutnya, enzim glukosiltransferase akan mentransfer gula-1-fosfat ke molekul pembawa lipofilik yang terikat pada membran sel. Setelah unit EPS terbentuk dalam sitoplasma, proses polimerisasi ekspor diperlukan untuk memindahkan unit EPS ke permukaan ekstraseluler dari membran sitoplasma dan untuk membangun polimer. Selanjutnya, polimer lengkap dikeluarkan dari sel dalam bentuk lendir atau melekat pada dinding sel membentuk kapsul.

EPS merupakan hasil metabolit sekunder BAL sehingga produksi EPS dipanen mulai jam ke-24 atau memasuki fase stasioner. Pada fase menjelang kematian, EPS yang diproduksi pada fase stasioner dapat dimanfaatkan kembali sebagai sumber karbon. Sumber karbon tersebut berasal dari degradasi EPS, akibat adanya enzim yang dihasilkan oleh bakteri itu sendiri. Sehingga, apabila masa pertumbuhan diperpanjang, hal ini dapat babkan penurunan produksi EPS. Selama fase eksponensial awal, biosintesis EPS tidak terjadi. Produksi EPS baru berjalan pada fase stasioner menuju kematian (Pham et al., 2000). Suhu dan waktu inkubasi akan mempengaruhi kadar EPS yang dihasilkan bakteri selama fase pertumbuhan (Malaka dan Effendi, 2007), nilai $\mathrm{pH}$ pada medium pertumbuhannya, tipe dari medium (Briczinski and Roberts, 2002), sumber karbon dan sumber mikromineral (Mozzi et al., 1996 ; van Hijum et al., 2009).

\section{SIMPULAN}

Berdasarkan amplifikasi gen gtf pada empat strain Weisella confusa yaitu Weisella confusa AS3, Weisella confusa AS14, Weisella confusa AS18 dan Weisella confusa AS21 menunjukkan bahwa ke-4 strain isolat tersebut memiliki gen gtf dengan ditunjukkan adanya pita DNA berukuran 660 bp dengan ketebalan yang bervariasi. Kemampuan produksi EPS tertinggi ditunjukkan oleh Weisella confusa AS3 yaitu sebesar $1883 \pm 56 \mathrm{mg} / \mathrm{l}$. 


\section{UCAPAN TERIMA KASIH}

Ucapan terima kasih peneliti sampaikan kepada Direktorat Jendral Pendidikan Tinggi, Kementrian Pendidikan Nasional Republik Indonesia yang telah mendanai penelitian ini melalui skema Pendanaan Penelitian Dosen Pemula (PDP) tahun 2018 berdasarkan Surat Keputusan Nomor 7/E/KPT/2019 tertanggal 19 Februari 2019 dan Perjanjian / Kontrak Nomor 111/SP2H/LT/DRPM/2019 tertanggal 11 Maret 2019.

\section{DAFTAR PUSTAKA}

Anindita, N.S., Novalina, D dan Sholikhah, A.N. 2018. Isolasi Dan Identifikasi Bakteri Asam Laktat Asal Air Susu Ibu Sebagai Kandidat Probiotik Dalam Pangan Kesehatan. Laporan Penelitian Dosen Pemula (PDP) 2018. Yogyakarta.

Badel, S.T., Bernardi, T and Michaud, P. 2011. New Prespectives for Lactobacilli Exopolysaccharides. Biotecnology Advances, 29: 54-56.

Briczinski, E.P and Roberts, R.F. 2002. Production of an Exopolysaccharide-Containing Whey Protein Concentrate by Fermentation of Whey. Journal Dairy Science, 85: 3189-3197.

Caggianiello, G., Kleerebezem, M and Spano, G. 2016. Exopolysaccharides produced by lactic acid bacteria: From health promoting benefits to stress tolerance mechanisms. Applied Microbiology and Biotechnology, 100: 3877-3886.

Carr, F.J., Chill, D and Maida, N. 2010. The lactic acid bacteria: a literature survey. Critical Reviews in Microbiology, 28: 281-370.

Castro-Bravo, N., Wells, J.M., Margolles, A., and Ruas-Madiedo, P. 2018. Interactions of surface exopolysaccharides from Bifidobacterium and Lactobacillus within the intestinal environment. Frontiers in Microbiology. 9:1-15.

Fraunhofer, M.E., Geissler, A.J., Jakob, F and Vogel, R.F. 2017. Multiple Genome Sequences of Exopolysaccharide-Producing, BreweryAssociated Lactobacillus brevis Strains. Genome Announcements. American Society For Microbiology, 5:26, 1-2.

Fukao, M., Zendo, T., Inoue, T., Nakayama. J., Suzuki, S., Fukaya, T., Yajima, N and Sonomoto, K. 2019. Plasmid-encoded glycosyltransferase operon is responsible for exopolysaccharide production, cell aggregation, and bile resistance in a probiotic strain, Lactobacillus brevis KB290. Journal of Bioscience and Bioengineering. 128(4):391-397.

Gayathiri, E., Bharathi, B., Velu, S., Siva, N., Natarajan, S., Prabavathi, S and Selvadhas, S. 2017. Isolation, Identification and Optimization of Exopolysaccharide Producing Lactic Acid Bacteria from Raw Dairy Samples. International Journal of Pharma And Chemical Research, 3:2, 202-211.

Gangoiti, J., Pijning, T and Dijkhuizen, L. 2018. Biotechnological potential of novel glycoside hydrolase family 70 enzymes synthesizing a-glucans from starch and sucrose. Biotechnology Advance. 36(1):196-207.

Halim, C.N dan Elok, Z. 2013. Studi Kemampuan Probiotik Isolat Bakteri Asam Laktat Penghasil Eksopolisakarida Tinggi Asal Sawi Asin (Brassica juncea). Jurnal Pangan dan Agroindustri, 1(1): 129-137.

Hidalgo-Cantabrana, C., Lopez, P., Gueimonde, M., De Los Reyes-Gavilan, G., Suarez, A., Margolles, A and Ruas-Madiedo, P. 2012. Immune modulation capability of exopolysaccharides synthesised by lactic acid bacteria and bifidobacteria. Probiotics and Antimicrobial Proteins, 4: 227-237.

Khalil, E.S., Manap, M.Y., Mustafa, S., Amid, M., Alhelli, A.M and Aljoubori, A. 2018. Probiotic characteristics of exopolysaccharides producing Lactobacillus isolated from some traditional Malaysian fermented foods. Journal of Food, 16:1, 287-298.

Kralj, S., van Geel-Schutten, G.H., van der Maarel, M.J.E.C and Dijkhuizen, L. 2003. Efficient screening methods for glucosyltransferase genes in Lactobacillus strains. Journal Biocatalysis and Biotransformation. 21:4-5. 
Leivers, S., Hidalgo-Cantabrana, C., Robinson, G., Margolles, A., Ruas-Madiedo, P and Laws, A. P. 2011. Structure of the high molecular weight exopolysaccharide produced by Bifidobacterium animalis subsp. Lactis IPLA-R1 and sequence analysis of its putative eps cluster. Carbohydrate Research. 346(17):2710-2717.

Li, Y., Li., Guo, S and Zhu, H. 2016. Statistical optimization of culture medium for production of exopolysaccharide from endophytic fungus Bionectria ochroleuca and its antitumor effect in vitro. EXLI J. 15: 211-220.

Malaka, R dan Effendi, A. 2007. Effec of incubation condition on the growth characteristics and exopolysaccharide production by ropy Lactobacillus delbrueckii subsp. bulgaricus. Buletin Penelitian Seri Hayati,7(2): 105-109.

Malik, A., Ariestanti, D.M., Nurfachtiyani, A dan Yanuar, A. 2008. Skrining Gen Glukosiltransferase (GTF) Dari Bakteri Asam Laktat Penghassil Eksopolisakarida. Makara Sains, 12:1, 1-6.

Malik, A., Radji, M., Kralj, S and Dijkhuizen, L. 2009. Screening of lactic acid bacteria from Indonesia reveals glucansucrase and fructansucrase genes in two dijerent Weissella confusa strains from soya. FEMS Microbiol Lett., 300: 131-138.

Malik, A., Hermawati, A.K., Hestiningtyas, M., Soemiati, A dan Radji, M. 2010. Isolasi dan skrining molekuler bakteri asam laktat pembawa gen glukansukrase dari makanan dan minuman mengandung gula. Makara, Sains. 14(1):63-68.

Meng, X., Gangoiti, J., Bai, Y., Pijning, T., Van Leeuwen, S.S and Dijkhuizen, L. 2016. Structure-function relationships of family GH70 glucansucrase and 4,6-aglucanotransferase enzymes, and their evolutionary relationships with family $\mathrm{GH} 13$ enzymes. Cellular and Molecular Life Sciences. 73(14):2681-2706.

Monchois, V., Willemot, R.M and Monsan, P. 2009. Glucansucrases: mechanism of action and structure-function relationships. FEMS Microbiol. Rev., 23:2, 131-151.

Mozzi, F., De Giori, G.S., Oliver, G and de Valdez, G.F. 1996. Exopolysaccahride production by Lactobacillus casei. Influence of salts. Michwissenshaft. 50(4): 186-188.

Nanda, A and Raghavan, C.M. 2014. Production and characterization of exopolysacharides (EPS) from the bacteria isolated from Pharma lab sinks. International Journal Pharmaceutical Technology Research 6:4, 1301-1305.

Nishimura, J. 2014. Exopolysaccharides Produced from Lactobacillus delbrueckii subsp. bulgaricus. Advances in Microbiology, 4: 1017-1023.

Nuraida, L., Winarti, S., Hana dan Prangdimurti, E. 2011. Evaluasi in vitro terhadap kemampuan bakteri asam laktat asal air susu ibu untuk mengasimilasi kolesterol dan mendekonjugasi garam empedu. Jurnal Teknologi dan Industri Pangan, 22:1, 46-52.

Nwodo, U.U., Green, E and Okoh, A.I. 2012. Bacterial exo-polysaccharides: functionality and prospects. International Journal Molecular Science, 13: 14002-14015.

Ozgun, D and Vural, H.C. 2011. Identification of Lactobacillus strains isolated from faecal specimens of babies and human milk colostrum by API $50 \mathrm{CHL}$ system. Journal of Medical Genetics and Genomics, 3:3, 46 - 49.

Peant, B., LaPointe, G., Gilbert, C., Atlan, D., Ward, P and Roy, D. 2005. Comparative analysis of the exopolysaccharide biosynthesis gene clusters from four strains of Lactobacillus rhamnosus. Microbiology. 151(6):1839-1851.

Pham, P.L., Dupont, I., Roy, D., Lapointe, G and Cerning, J. 2000. Production of Exopolysaccharides by Lactobacillus Rhamnosus And Analysis of Its Enzymatic Degradation During Prolonged Fermentation. Applied Environmental Microbiology, 66: 2302-2310.

Polak-Berecka, M., Choma, A., Wasko, A., Gorska, S., Gamian, A and Cybulska, J. 2015. Physicochemical characterization of exopolysaccharides produced by Lactobacillus rhamnosus on various carbon sources. Carbohydrate Polymers, 117: 501-509.

Rawal, P.M., Chauhan, P.B., Prajapati, H and Gahlout, M. 2016.Evaluation of cultivation condition for enhanced production of exopolysaccharide by bacterial isolate $P 11$ under submerged culture condition. International Journal Advanced Research Biology Science, 3:5, 183-190. 
Ruas-Madiedo, P., Moreno, J.A., Salazar, N., Delgado, S., Mayo, B., Margolles, A and de los Reyes-Gavilan, C.G. 2007. Screening of Exopolysaccharide-Producing Lactobacillus and Bifidobacterium Strains Isolated from the Human Intestinal Microbiota. Applied Environmental Microbiology, 73:13, 4385-4388.

Ryan, P.M., Ross, R.P., Fitzgerald, G.F., Caplice, N.M and Stanton, C. 2015. Sugar-coated: Exopolysaccharide producing lactic acid bacteria for food and human health applications. Food and Function, 6: 679-693.

Sanlibaba, P and Çakmak, G.A. 2016. Exopolysaccharides production by lactic acid bacteria. Applied Microbiology 2:2, 1-5.

Serrano-Nino J.C., Solis-Pacheco, J.R., Gutierrez-Padilla, J.A., Cobian-Garcia, A., CavazosGarduno, A., Gonzalez-Reynoso, O and Aguilar-Uscanga, B.R. 2016. Isolation and Identification of Lactic Acid Bacteria from Human Milk with Potential Probiotic Role. Journal of Food and Nutrition Research, 4:3, 170-177.

Solieri, L., Bianchi, A., Mottolese, G., Lemmetti, F and Giudici, P. 2014. Tailoring the probiotic potential of non-starter Lactobacillus strains from ripened Parmigiano Reggiano cheese by in vitro screening and principal component analysis. Food Microbiology, 38: 240-249.

Song, J., Lee, S.C., Kang, J.W., Baek, H.J and Suh, J.W. 2004. Phylogenetic Analysis of Streptomyces spp. Isolated from Potato Scab Lesions in Korea on the Basis of 16S rRNA Gene and 16S-23S rDNA Internally Transcribed Spacer Sequences. International Journal System Evolution Microbiology, 54: 203-209.

Stack, H.M., Kearney, N., Stanton, C., Fitzgerald, G.F and Ross, R.P. 2010. Association of beta-glucan endogenous production with increased stress tolerance of intestinal Lactobacilli. Applied and Environmental Microbiology. 76(2):500-507.

Suryawira, Y. M. 2011. Produksi Eksopolisakaridaoleh Bakteri asam Laktat Pada Medium Sari Kurma dan Sari Murbei. Skripsi. Universitas Brawijaya. Malang.

Tieking, M., Korakli, M., Ehrmann, M.A., Ganzle, M.G and Vogel, R.F. 2010. In situ production of exopolysaccharides during Sourdough fermentation by cereal and intestinal isolates of lactic acid bacteria. Applied Environmental Microbiology. 69:2, 945-52.

Torino, M.I., Font de Valdez, G and Mozzi, F. 2015. Biopolymers from lactic acid bacteria. Novel applications in foods and beverages. Frontier in Microbiolology, 6: 1-16.

van Hijum, S.F.A.T., Kralj, S., Ozimek, L.L., Dijkhuizen, L and van Geel-Schutten, G.H. 2009. Structure-function relationships of glucansucrase and fructansucrase enzymes from lactic acid bacteria. Microbiol Mol Biol Rev., 70:1, 157-176.

Venkateswarulu, T.C., Chakravarthy, K., Reddy, R., Babu, J and Kodali, V. 2016. Morphological and biochemical characterization of exopolysaccharide producing bacteria Isolated from dairy effluent indira M1. Pharmaceutical Science Research, 8:2, 88-91.

Widodo., Taufiq, T.T., Aryati, E., Kurniawati, A and Asmara, W. 2012. Human origin Lactobacillus casei isolated from Indonesian infants demonstrating potential characteristics as probiotics in vitro. Indonesian Journal Biotechnology 17:1, 79-89.

Yan, S., Zhao, G., Liu, X., Zhao, J., Zhang, H and Chen, W. 2017. Production of exopolysaccharide by Bifidobacterium longum isolated from elderly and infant feces and analysis of priming glycosyltransferase genes. The Royal Society of Chemistry. RSC Adv., 7: 31736-31744. 